\title{
Foreign research and development in China: a sectoral approach
}

\author{
Yifei Sun \\ Department of Urban and Regional Economy, \\ East China Normal University, \\ Shanghai, China \\ and \\ Department of Geography, \\ California State University, Northridge, \\ 18111 Nordhoff St., Northridge, CA 91330-8249, USA \\ E-mail: Yifei.sun@csun.edu
}

\begin{abstract}
This study systematically examines foreign R\&D in China's manufacturing industries, using the most recent census data published by China's State Council. It reveals that foreign firms are committing less R\&D resource than China's domestic enterprises. Foreign R\&D activities are far more active in high-tech industries than in labour-intensive industries. This study also demonstrates that China's dynamic domestic market and export, as well as its large pool of well-educated labour are the major drivers for foreign $\mathrm{R} \& \mathrm{D}$, while the technology drive is not significant yet. Finally, the result shows that foreign firms are less likely to conduct $R \& D$ in sectors where they possess strong advantages. Such results suggest that the Chinese governments and domestic firms should focus on building up indigenous innovative capabilities in order to attract more foreign R\&D: the majority of foreign firms will invest in $R \& D$ when they feel the competition from domestic firms.
\end{abstract}

Keywords: globalisation; research and development; R\&D; multinational corporation; MNC; comparative advantage; sectoral distribution; manufacturing; China.

Reference to this paper should be made as follows: Sun, Y. (2010) 'Foreign research and development in China: a sectoral approach', Int. J. Technology Management, Vol. 51, Nos. 2/3/4, pp.342-363.

Biographical notes: Yifei Sun is an Associate Professor at the Department of Geography at California State University, Northridge. He also holds the Zijiang Chair Professor in Economic Geography at East China Normal University. His research interests concentrate on technology, innovation and urban and regional economic development in China. His recent work focuses on global R\&D in China and technology catch-up in China's information communication industry.

\section{Introduction}

Multinational corporations (MNCs) are increasingly adopting a global research and development (R\&D) strategy. Overseas R\&D spending has been growing at a faster pace 
than domestic counterparts and is playing an increasingly important role in global technological development. According to the data reported in National Science and Engineering Indicator (NSF, 2006), the share of R\&D performed abroad by US MNCs in their overall R\&D expenditure has increased from $11.5 \%$ to $13.3 \%$. Such a trend helps explain that R\&D globalisation has become an increasingly important topic for academics, policy makers and the public in large (Behrman and Fisher, 1980; Mansfield et al., 1979; Ronstadt, 1977).

Traditionally, advanced economies have been the major origins and destinations of global R\&D investment. The NSF (2006) report has made some data on this aspect available as well. In 1994, R\&D performed in Europe was about $73.05 \%$ of US MNCs' overseas R\&D spending while another $9.51 \%$ and $7.04 \%$ was conducted in Japan and Canada respectively. Since then, developed countries have witnessed weakened positions while developing countries, particularly those in the Asia/Pacific region have benefited significantly during such a process. The share of Asia/Pacific countries (excluding Australia and Japan) in US MNCs' overseas R\&D budget increased from 3.49\% in 1994 to $10.02 \%$ in 2002 . In particular, China and India have become the major beneficiaries. In 1994, US MNCs spent $\$ 7$ million on R\&D in China and such expenditure rocketed up to $\$ 646$ million in 2002. Consequently, China's share in US MNCs' overseas R\&D budget grew from $0.06 \%$ to $3.05 \%$, the 8 th largest among the 32 countries with reported data, leaving behind many developed countries such as Italy, Belgium, Netherlands, Switzerland and Australia. Indeed, China ranks first among both developed and developing economies in a few recent international surveys asking MNCs where their future R\&D centres will likely be located (EIU, 2004; UNCTAD, 2005).

Despite its increasing importance, foreign R\&D in developing countries only recently has received some attention (Gassmann and Han, 2004; GEI, 2001; Reddy, 1997; Reddy and Sigurdson, 1997; Sun, 2003; Sun et al., 2006, 2008; Sun and Wen, 2007a, 2007b; von Zedtwitz, 2004; Walsh, 2007; Xue et al., 2001). This study wishes to contribute to the field of R\&D globalisation in general and foreign R\&D in China in particular on a few fronts. First, it aims to examine the sectoral difference of R\&D performed by MNCs in a foreign country, a topic largely overlooked by the existing literature. Previous studies on globalisation of $R \& D$ have focused on the national scale and only recently a number of studies have started to look at the issues at the subnational scale. Such studies have concentrated on questions such as why certain countries are more attractive, how foreign R\&D investments are located with a country and why some locales are more attractive than others. Interestingly, to my knowledge, no studies have examined the sectoral distribution of foreign $\mathrm{R} \& \mathrm{D}$ in detail. Most often, the data on industrial distribution of foreign R\&D in a country are simply reported, but no further questions are asked: Why are certain sectors more attractive than others in attracting foreign R\&D? The lack of such studies could be because of shortage of data required for such exercises. Still it could be attributed to an implicit assumption among the studies: the reasons accounting for the presence of foreign $R \& D$ at various sectors would be of no difference from those operating at the national scale. Yet whether or not this is the case remains to be explored.

Second, this study explores how parent company's comparative advantages in market and technology affect their R\&D decisions in a foreign country. The existing literature has emphasised the importance of three factors - market, human resources and technology - in explaining R\&D globalisation. The role of comparative advantage in this 
process has rarely been examined, though propriety advantage of foreign companies is a critical component in all theories on foreign investment in general. Is comparative advantage a significant factor in MNCs' R\&D investment decisions? I want to address the question in this study using the recently published data in China.

Finally, I wish to clarify some issues regarding foreign R\&D in China. Many existing studies on foreign R\&D in China have largely relied on a small number of ad hoc interviews (Sun, 2003; Sun et al., 2006; Sun and Wen, 2007a, 2007b; von Zedtwitz, 2004). However, basic issues such as how much foreign R\&D has been invested in China and how they are distributed are not clear. Taking advantage of the recently published data from China's first economic census, this study will offer some information on this regard. The data also enable me to take a statistical approach in this study and I hope such statistical analyses will enrich our understanding of foreign R\&D in China.

The paper is organised as follows. Section 2 reviews briefly MNCs' motivations of conducting R\&D in foreign countries and related hypotheses are developed. In Section 3, the model and data are specified. Section 4 reports the results of analyses, and Section 5 concludes the study.

\section{Literature review}

Numerous studies have identified the factors that favour decentralised R\&D activities and such factors range from the demand, supply and governmental regulations. On the demand-side, the following needs have been identified:

1 to adapt parent company's product and process technologies for foreign markets (Behrman and Fisher, 1980; De Meyer and Mizushima, 1989; Dunning, 1993; Florida, 1997; Kuemmerle, 1997, 1999; Ronstadt, 1977)

2 to support parent companies' manufacturing and marketing activities in foreign markets (De Meyer and Mizushima, 1989; Florida, 1997; Hakanson and Nobel, 1993; Kuemmerle, 1997, 1999)

3 to monitor demands in foreign markets (Florida, 1997)

4 to develop new products to serve unique demands of foreign markets (Florida, 1997; Kuemmerle, 1997, 1999).

On the supply-side, the importance of the following factors has been revealed:

1 to relieve the shortage of skilled labour forces in the home country (De Meyer and Mizushima, 1989; Terry, 1996)

2 to lower the costs of technological efforts (Terry, 1996)

3 to monitor scientific and technological development in foreign countries (Florida, 1997; Florida and Kenney, 1994)

4 to tap into foreign countries' scientific infrastructure in order to conduct long-term research and development for the global markets (De Meyer and Mizushima, 1989; Florida and Kenney, 1994; Kuemmerle, 1997)

5 to build competitive advantage through a global network of capabilities (Bartmess and Cerny, 1993). 
Finally, previous studies have shown that governments in host countries may require MNCs to upgrade their investments and to conduct R\&D activities locally (Hakanson and Nobel, 1993). The decentralisation of R\&D is further enabled and facilitated by advances in telecommunication technologies (Howells, 1990, 1995).

The few studies on foreign R\&D in developing countries (Gassmann and Han, 2004; GEI, 2001; Reddy, 1997; Reddy and Sigurdson, 1997; Sun, 2003; Sun et al., 2006; Sun and Wen, 2007a, 2007b; von Zedtwitz, 2004; Walsh, 2003; Xue et al., 2001) have confirmed the findings from the general studies on foreign $R \& D$, and factors from both the demand side and the supply side are important in explaining the recent surge of R\&D performed by foreign companies. In the case of China, its growing domestic market and increasing roles as a 'world's factory', as well as its large pool of well-educated labour have become a huge attraction to foreign companies. China has become the top markets for many products. Many foreign invested enterprises have served China's expanding domestic market as well as the world market. Overall, foreign invested enterprises in China are exporting about $45 \%$ of their products manufactured in China (China State Council, 2006). As such, both China's domestic market and its attraction as an export base have become important considerations for foreign R\&D.

Hypothesis 1 Sectors with larger domestic market will attract more foreign R\&D.

Hypothesis 2 Sectors where foreign invested enterprises are more export-oriented will attract more foreign $R \& D$.

On the supply side, China is endowed with a large pool of well-educated labour while the labour cost is much lower than that in developed countries. China had more than 1700 universities and colleges, with more than 15 million students enrolled in tertiary education (CSSB, 2006). Meanwhile, each year more than 4.5 million new students are admitted to its higher education system and more than half a million students with degrees in science and engineering (BS and above) graduate from its universities. According to some experts, China will produce more PhDs in S\&T than the USA by 2010 (Freeman, 2005). This huge pool of highly educated labour has been revealed by many previous studies to be an important consideration when MNCs decide to establish $\mathrm{R} \& \mathrm{D}$ facilities there. The lower labour cost further adds to China's attraction and this has been observed by previous studies as well (Sun, 2003; Sun et al., 2006; von Zedtwitz, 2004). The lower wages for educated people in some sectors may also indicate the waste and under-use of human resources. I expect such sectors will be particularly attractive for foreign companies, who can afford higher pay for their employees. As such, I develop the third and fourth hypotheses:

Hypothesis 3 Sectors with more better-educated people are more likely to attract more foreign R\&D.

Hypothesis 4 Sectors with lower wages for better-educated people are more likely to attract more foreign $R \& D$.

Scholars have also agreed that the technology-driven foreign $R \& D$ has not become significant in China, despite that some high-profile cases such as those from Microsoft, Motorola, Intel and Lucent technologies, and a number of other cases are conducting strategic R\&D there (Sun, 2003; von Zedtwitz, 2004). In a recent report, Schwaag Serger (2006) estimated that only about 30 foreign R\&D centres are 'truly innovative', while the 
majority of foreign R\&D are involved in product adaptation and customisation. As such, I expect that:

Hypothesis 5 Technology endowment will not explain the industrial difference of foreign $\mathrm{R} \& \mathrm{D}$ in China.

As pointed in the previous section, the literature on globalisation of R\&D has largely ignored the comparative advantage of MNCs in their decisions of R\&D investments in foreign countries, though such a factor has been emphasised in explaining MNCs' decisions regarding general foreign investments. The advantages possessed by a firm are a critical component in Dunning's OLI paradigm of eclectic theory on foreign investment. Such ownership advantages may include propriety technology and management expertise, among many others. I argue that if foreign companies possess obvious competitive advantages in comparison to domestic firms, they may not need to conduct $\mathrm{R} \& \mathrm{D}$ in the foreign country, since they can capture the market and profits relatively easily. In contrast, foreign companies with weaker positions may have to conduct $\mathrm{R} \& \mathrm{D}$ in order to enhance their market competitiveness. As such, a negative relationship between a company's strength and their $R \& D$ presence in foreign countries is anticipated. This leads to the sixth hypothesis:

Hypothesis $6 \quad$ Foreign companies will invest less in sectors where they possess stronger advantages against their domestic competitors.

Still, some argue that foreign companies come to China because of governmental pressure, since the Chinese governments have adopted a 'market for technology' policy for a long time (Walsh, 2003). It is one of the government's major goals to attract foreign investors in order to upgrade its domestic technology development capabilities. However, many studies have revealed that while government pressure was an important factor in MNCs' earlier decision to establish R\&D facilities, it has little to do with the recent surge of foreign R\&D in China (Sun et al., 2006; Walsh, 2003). Foreign R\&D has been driven largely by business considerations. But the role of governments may be manifested in other aspects: foreign investors are restricted from some sectors, in which state-owned enterprises (SOEs) are more favoured. I expect that foreign investors will avoid those sectors where SOEs are particularly strong.

Hypothesis 7 Foreign R\&D presence is negatively associated with SOEs presence in different sectors.

To summarise, $R \& D$ in foreign countries is the result of multiple factors, from market to human resource, and from technology and competitive advantage to government policies. I want to see what factors are more important in explaining the sectoral difference of foreign R\&D in China.

\section{The model and data}

\subsection{Model specification}

Basically, I assume that foreign R\&D is affected by the five categories of factors identified in the previous section. A linear combination of these factors is used to explain the presence of foreign $\mathrm{R} \& \mathrm{D}$ in different sectors. 


$$
\text { FOR_RD } \mathrm{RD}_{\mathrm{i}}=\mathrm{F}\left(\mathrm{DEMAND}_{\mathrm{i}}, \mathrm{HR}_{\mathrm{i}}, \mathrm{TECH}_{\mathrm{i}}, \mathrm{COM}_{\mathrm{i}}, \mathrm{SOE}_{\mathrm{i}}, \mathrm{DOM}_{-} \mathrm{RD}_{\mathrm{i}}\right)
$$

where FOR_RD denotes the foreign R\&D presence in a sector, DEMAND, HR, TECH, COM and SOE represent the vectors of factors in market demand, human resources, technology endowment, competitive advantage of foreign firms in relative to Chinese domestic firms and the presence of SOEs in each sector respectively. Dom_RD measures the presence of domestic R\&D in a sector and is included as a control variable. DEMAND consists of two different measurements, the domestic market size for a sector (DomMkt) and the export orientation of foreign invested companies in each sector (ForExprt). HR includes the availability of technical staff (STStaff) ${ }^{1}$ and their wages (STWage). TECH measures the technology endowment in a sector and in this study I use the number of invention patents produced by the S\&T staff (Patent_STStaff) ${ }^{2}$. For the variable of STWage, I also include a variable with STWage adjusted by the productivity of S\&T staff (AdjSTWage). In the literature on foreign direct investment, many studies have found that the relationship between absolute wage and foreign investments is not conclusive (He, 2003). In some studies, the relationship appears to be negative while in others opposite results have been reported. In contrast, authors using adjusted wages have found consistent negative relationships. In this study, adjusted wage is measured by the ratio between STWage and Patent_STStaff.

The competitiveness of foreign firms is measured by two indicators, their market share in China's domestic market (FMkt_Monoply) and their productivity in relation to Chinese domestic firms. Productivity can be measured against labour or capital. In this study, I use the total factor productivity (TFP) instead of labour/capital productivity, since it evaluates technological progress and constitutes a comprehensive measurement of the efficiency with which the factors of production are employed (Liu and Wang, 2003). In particular, I use the FTP ratio between foreign companies and Chinese domestic firms (FORFTP_DOMFTP) to represent the relative strength of foreign companies in a sector. To estimate FTP for foreign firms and domestic firms in a sector, I use the traditional production function.

$$
\mathrm{Y}_{\mathrm{i}}=\mathrm{A} \mathrm{K}_{\mathrm{i}}{ }^{\alpha} \mathrm{L}_{\mathrm{i}}^{\beta}
$$

where $\mathrm{Y}$ denotes the gross output value of firms in a sector, $\mathrm{K}$ and $\mathrm{L}$ are physical capital and labour inputs in each sector respectively. $A$ simply measures the TFP, and $\alpha$ and $\beta$ represent the elasticity of the factors of production in the model. Equation (2) can be rewritten in natural logarithms and TFP can be calculated as the follows.

$$
\operatorname{LnA}=\operatorname{LnY}-\alpha \operatorname{LnK}-\beta \operatorname{LnL}
$$

To estimate the TFP for foreign firms and Chinese firms in each sector, I pool together the sectoral data for foreign firms and Chinese firms to estimate the production function. Of course, such an approach assumes that foreign firms and domestic firms share the same production function. To test whether or not the assumption holds, I will apply the Chow's test.

The variable SOE can be easily defined as the share of SOEs in a sector's sales. Finally, I also include a control variable to measure the presence of R\&D by Chinese domestic enterprises (DOM_RD). As such, equation (1) can be rewritten as: 


$$
\begin{aligned}
\text { FOR_RD }_{\mathrm{i}} & =\alpha_{0}+\alpha_{1} \text { DomMkt }_{\mathrm{i}}+\alpha_{2} \text { FExprt }_{\mathrm{i}}+\alpha_{3} \text { STStaff }_{\mathrm{i}}+\alpha_{4} \text { STWage }_{\mathrm{i}} \\
& +\alpha_{5} \text { Patent_STStaff }_{\mathrm{i}}+\alpha_{6} \text { FMkt_Monoply }_{\mathrm{i}}+\alpha_{7} \text { ForFTP_DomFTP }_{\mathrm{i}} \\
& +\alpha_{8} \text { SOE }_{\mathrm{i}}+\alpha_{9} \text { DOM_RD }_{\mathrm{i}}+\varepsilon_{\mathrm{i}}
\end{aligned}
$$

As many have pointed out that one potential problem with cross-sectional data is heteroscedasticity, the existence of which will makes OLS estimators inefficient. I will use the White's test to detect whether or not heteroscedasticity is a problem. If so, I will use White's standard errors to make the correction.

\subsection{Data}

The data used in this study came from the China Economic Census Yearbook (China State Council, 2006). This was the first effort made by the Chinese government to collect data on all economic units. The census covered all sectors in the secondary and tertiary industries in China and includes a wide range of data. The published data consists of three major parts. The first part includes basic information such as name, address, sector, date of establishment, ownership, employment, sales and capital, among others. The second part focuses on financial data, including detailed information on asset, investment, production, sales, income, costs, tax, profit and others. The third part concentrates on industrial data, including information about production and sales, inventory, equipment, energy consumption, raw material consumption and S\&T. The officially published data consist of four volumes: the first volume on overall data, the second and third volumes on the secondary industry and the fourth volume on the tertiary sector. All the data are tabulated by sector and province. Most data are reported at twodigit sector level while certain data are reported at the three-digit and even four-digit sector levels. This study focuses on the data at the 29 sectors at the two-digit level in the manufacturing industry, for which all the necessary data are available. It is unfortunate that more detailed data are not available to the public yet. The published data also focus on those firms whose annual sales are above five million RMB Yuan, while only a few selected indicators for smaller firms are reported. As such, I will focus on those 'bigger' firms.

In this study, the presence of foreign R\&D in a sector is measured in two different ways:

1 the number of S\&T institutes established by foreign firms (FRD_Inst) ${ }^{3}$

2 R\&D spending by foreign firms (FRD_Exp).

The definition of S\&T institutes is much broader than the definition of R\&D centres. According to the documentation (China State Council, 2006),

"S\&T activities refer to organised activities that are related to the production, development, distribution and application of S\&T knowledge in the fields of natural science, agricultural science, engineering and technological sciences, and human and social sciences. S\&T activities can be classified into three categories: research and development activities $(R \& D)$, diffusion of $R \& D$ results and related services." 
In the 2004 census, only the former two categories are included and they are commonly referred to technological development activities in China. As such, S\&T activities reflect the technological efforts, broader than R\&D in scope.

"Industrial S\&T institutes refer to those solely established by the firms or establishments in collaboration with other organisations. Such institutes may be affiliated with manufacturing facilities but are relatively independent in administration or those independently administrated institutes with a focus on S\&T activities. Examples include technology centres, R\&D institutes, development centres, development departments and laboratories... Such S\&T institutes do not include those administrative offices with firms, neither are S\&T institutes established by firmed outside China."

Table 1 Variable definitions

\begin{tabular}{cl}
\hline Dependent variable & \\
\hline FRD_Inst & The number of foreign S\&T institutes in a sector \\
FRD_Exp & R\&D spending by foreign invested enterprises (in billion RMB \\
& Yuan) \\
\hline Independent variables & The sales in China's domestic market (billion RMB Yuan), \\
\hline DomMkt & which represents the Chinese domestic market size \\
The share of export out of total sales for foreign firms in China \\
(\%), which refers to the export orientation of foreign firms in a \\
sector in China \\
The percent of employees engaged in S\&T for a sector (\%), \\
which represents the availability of quality labour in a sector \\
The average annual wage for S\&T staff in a sector (Yuan) \\
Average number of inventive patents per 10,000 S\&T \\
employees \\
PTWage
\end{tabular}


According to the census, among the 276,474 firms with annual sales above five million RMB Yuan, 32,924 (12.4\%) of them reported to have S\&T activities, 17,075 (6.2\%) of them reported to conduct R\&D and 13,906 (5.03\%) of them reported to have set up S\&T institutes.

The census classifies firms into three major types according to ownership: Chinese domestically owned firms, firms with investments from Hong Kong, Marco and Taiwan (HKMT), and foreign invested enterprises (FIEs). It would be helpful to separate the HKMT firms from FIEs when examining their R\&D activities in China. However, certain data critical for the statistical analyses - sales, employment, asset, among others - are not reported separately. As such, I will combine HKMTs and FIEs in the statistical modelling, while information about these two types of foreign firms will be reported separately when possible. ${ }^{4}$ From the census, I extract all the variables as defined in Table 1.

\section{Empirical results}

\subsection{The presence of foreign $R \& D$ in China}

Previous studies have revealed that foreign $R \& D$ concentrated in sectors such as information and communication industries (GEI, 2001; von Zedtwitz, 2004; Xue et al., 2001). It has also been assumed by many studies that foreign firms are less likely to engage in R\&D than domestic firms (Sun, 2002). The economic census data largely confirm both observations (Tables 2 and 3). However, the data in Tables 2 and 3 also show a few interesting observations. First, about $12.7 \%$ of FIEs are conducting R\&D, while only about $5.2 \%$ of HKMT enterprises and $6.5 \%$ of Chinese domestic enterprises report so. Such an observation shows that FIEs are more likely to engage in R\&D than either HKMT enterprises or Chinese domestic enterprises. However, if one considers the R\&D intensity, Chinese domestic enterprises do perform better than FIEs or HKMT invested enterprises. On average, Chinese domestic enterprises spend about $0.63 \%$ of their incomes on R\&D while foreign invested firms (including FIEs and HKMT invested firms) in China spend about $0.37 \%$ of their income on R\&D. Similarly, Chinese domestic firms commit more human resources on R\&D than foreign firms $(1.44 \%$ versus $0.92 \%)$. The above two observations indicate that foreign enterprises may be more likely to engage in $\mathrm{R} \& \mathrm{D}$, but Chinese domestic enterprises are committing more resources. These two observations suggest the majority of foreign R\&D in China is minor and adaptive in nature, which does not necessarily require significant inputs.

Second, Table 2 shows that more foreign invested firms are conducting more R\&D than those setting up formal R\&D institutes. About $15 \%$ of FIEs reported to conduct R\&D in China, though only about $5 \%$ of them had set up S\&T institutes. Overall, about 1,400 FIEs and 1,200 HKMT invested enterprises have set up 3,204 S\&T institutes in China. These figures are much larger than 750 , the number of $R \& D$ facilities that have been widely circulated in the media ${ }^{5}$. However, I have some doubts about the accuracy on 
the number of S\&T institutes, although, the census document has a detailed definition. My further examination of the data shows that the regional distribution of foreign S\&T institutes (based on the Economic Census) is significantly different from that for foreign $R \& D$ centres revealed by many previous studies. In particular, Beijing's share in foreign $S \& T$ institutes is significantly lower than its share of foreign $R \& D$ centres. Furthermore, Beijing reported to have fewer foreign S\&T institutes than foreign R\&D centres, which is impossible according to their definition. I argue that such a discrepancy could be due to a few reasons. First of all, firms in China do not have the number of S\&T institutes in their accounting book, though they do keep data R\&D spending and personnel, since such items are required by the regulations, according to our discussion with many firms. Second, I suspect that such a discrepancy could be due to the difference of the data collecting agencies. For the census data, the State Statistics Bureau was the major organiser, while the Ministry of science and Technology and the Ministry of Commerce were the collectors for foreign R\&D data. The two ministries are in charge of policies for foreign R\&D. Naturally, foreign companies should be more interested in collaborating with them than with the State Statistics Bureau. As such, I will not include the S\&T institute data for the final analyses.

Third, foreign R\&D in China is highly concentrated in a few sectors and the leading sectors include medical and pharmaceutical products, transport equipments, electronic and telecommunication, instruments/meters/culture and office machinery, electric equipment and machinery, general machinery, metal products and chemical fibres. Such industries are high-tech in nature and require more R\&D than labour-intensive industries such as food production, textile and garments. For example as many as $38.5 \%$ of FIEs in the medical and pharmaceutical industries have reported to conduct some R\&D. Such patterns are similar to what can be seen for Chinese domestic enterprises and HKMT invested enterprises.

Finally, in most sectors, Chinese domestic enterprises are contributing more resources to R\&D than foreign enterprises (Table 3). Particularly differences in sectors such as electronic and telecommunication, offices machinery, and electric equipment and machinery are particularly strong. For instance, Chinese enterprises in the electronic and telecommunication industry contribute $3.49 \%$ of their income to R\&D, much higher than the corresponding $0.64 \%$ for their foreign counterparts. Interestingly, foreign invested enterprises in a few sectors such as non-ferrous metal, non-metal mineral products, printing, paper products, furniture, textile and garment, did report slightly higher R\&D intensity (in terms of spending) than Chinese domestic enterprises. It is also interesting to note that all such sectors fall into the traditional and low-tech industries. It is not clear why it is the case for the time being. 
Table 2 Foreign S\&T in China by sector I

\begin{tabular}{|c|c|c|c|c|c|c|}
\hline & \multicolumn{2}{|c|}{$\begin{array}{c}\text { HKMT } \\
\text { enterprises }\end{array}$} & \multicolumn{2}{|c|}{ FIEs } & \multicolumn{2}{|c|}{ Total } \\
\hline & Total & $\begin{array}{l}W . \\
R \& D \\
(\%)\end{array}$ & Total & $\begin{array}{l}W . \\
R \& D \\
(\%)\end{array}$ & Total & $\begin{array}{l}W . \\
R \& D \\
(\%)\end{array}$ \\
\hline Total & 200587 & 6.5 & 28013 & 5.2 & 28399 & 12.7 \\
\hline Food processing & 11964 & 2.8 & 741 & 4.2 & 1392 & 5.7 \\
\hline Food manufacturing & 4256 & 5.6 & 516 & 5.2 & 756 & 8.5 \\
\hline $\begin{array}{l}\text { Beverage } \\
\text { manufacturing }\end{array}$ & 2905 & 7.0 & 210 & 4.8 & 354 & 15.0 \\
\hline Tobacco processing & 203 & 31.0 & 4 & 25.0 & 3 & 0.0 \\
\hline Textile industry & 18956 & 3.2 & 3020 & 3.0 & 2216 & 7.5 \\
\hline $\begin{array}{l}\text { Garments and other } \\
\text { fibre products }\end{array}$ & 6911 & 2.1 & 2745 & 1.5 & 2373 & 4.3 \\
\hline $\begin{array}{l}\text { Leather, furs, down } \\
\text { and related products }\end{array}$ & 3869 & 2.3 & 1366 & 1.9 & 1158 & 6.7 \\
\hline $\begin{array}{l}\text { Timber processing, } \\
\text { bamboo, cane, palm } \\
\text { fibre and straw } \\
\text { products }\end{array}$ & 4087 & 1.7 & 487 & 2.3 & 443 & 4.5 \\
\hline $\begin{array}{l}\text { Furniture } \\
\text { manufacturing }\end{array}$ & 1966 & 2.1 & 557 & 1.1 & 502 & 5.8 \\
\hline $\begin{array}{l}\text { Papermaking and paper } \\
\text { products }\end{array}$ & 6251 & 2.2 & 734 & 2.3 & 488 & 7.0 \\
\hline $\begin{array}{l}\text { Printing and record } \\
\text { medium reproduction }\end{array}$ & 4443 & 1.6 & 420 & 4.3 & 276 & 8.3 \\
\hline $\begin{array}{l}\text { Cultural, educational } \\
\text { and sports goods }\end{array}$ & 1796 & 4.4 & 920 & 2.3 & 666 & 5.7 \\
\hline $\begin{array}{l}\text { Petroleum processing } \\
\text { and coking }\end{array}$ & 1855 & 5.6 & 69 & 5.8 & 95 & 8.4 \\
\hline $\begin{array}{l}\text { Raw chemical } \\
\text { materials and chemical } \\
\text { products }\end{array}$ & 15748 & 9.4 & 1399 & 7.6 & 1612 & 15.8 \\
\hline $\begin{array}{l}\text { Medical and } \\
\text { pharmaceutical } \\
\text { products }\end{array}$ & 3829 & 22.9 & 354 & 30.5 & 526 & 38.2 \\
\hline Chemical fibre & 1234 & 8.3 & 183 & 7.1 & 119 & 17.6 \\
\hline Rubber products & 2385 & 6.5 & 382 & 2.9 & 401 & 14.7 \\
\hline Plastic products & 8782 & 3.8 & 1985 & 3.3 & 1502 & 7.7 \\
\hline
\end{tabular}

Notes: Total: total number of enterprises with annual sales above five million RMB Yuan, with R\&D: percent of firms with R\&D, with S\&T Inst. percent of firms with S\&T institutes. 
Table 2 Foreign S\&T in China by sector I (continued)

\begin{tabular}{|c|c|c|c|c|c|c|}
\hline & \multicolumn{2}{|c|}{$\begin{array}{c}\text { HKMT } \\
\text { enterprises }\end{array}$} & \multicolumn{2}{|c|}{ FIEs } & \multicolumn{2}{|c|}{ Total } \\
\hline & Total & $\begin{array}{c}W . \\
R \& D \\
(\%)\end{array}$ & Total & $\begin{array}{c}W . \\
R \& D \\
(\%)\end{array}$ & Total & $\begin{array}{c}W . \\
R \& D \\
(\%)\end{array}$ \\
\hline $\begin{array}{l}\text { Non-metal mineral } \\
\text { products }\end{array}$ & 17537 & 3.8 & 1172 & 6.6 & 1251 & 11.0 \\
\hline $\begin{array}{l}\text { Smelting and pressing } \\
\text { of ferrous metals }\end{array}$ & 6629 & 3.4 & 240 & 7.9 & 272 & 11.8 \\
\hline $\begin{array}{l}\text { Smelting and pressing } \\
\text { of non-ferrous metals }\end{array}$ & 4649 & 6.1 & 336 & 5.4 & 315 & 16.2 \\
\hline Metal products & 11307 & 3.4 & 1450 & 3.0 & 1374 & 7.2 \\
\hline Ordinary machinery & 17488 & 8.1 & 1168 & 6.8 & 1913 & 17.6 \\
\hline $\begin{array}{l}\text { Special purpose } \\
\text { equipment }\end{array}$ & 8851 & 13.4 & 914 & 8.4 & 1160 & 17.8 \\
\hline Transport equipment & 9815 & 9.2 & 760 & 7.9 & 1248 & 24.5 \\
\hline $\begin{array}{l}\text { Electric equipment and } \\
\text { machinery }\end{array}$ & 12219 & 10.1 & 2012 & 7.9 & 1914 & 18.7 \\
\hline $\begin{array}{l}\text { Electronic and } \\
\text { telecommunications } \\
\text { equipment }\end{array}$ & 4484 & 21.3 & 2231 & 10.9 & 2446 & 21.7 \\
\hline $\begin{array}{l}\text { Instruments, meters, } \\
\text { cultural and office } \\
\text { machinery }\end{array}$ & 2614 & 21.3 & 578 & 11.1 & 724 & 20.0 \\
\hline Art and others & 3268 & 3.2 & 1026 & 1.4 & 834 & 5.3 \\
\hline
\end{tabular}

Notes: Total: total number of enterprises with annual sales above five million RMB

Yuan, with R\&D: percent of firms with R\&D, with S\&T Inst. percent of firms

with S\&T institutes.

Table 3 Foreign R\&D in China by sector II

\begin{tabular}{|c|c|c|c|c|c|c|}
\hline \multirow[t]{3}{*}{ Sectors } & \multicolumn{2}{|c|}{$\begin{array}{c}\text { Domestic } \\
\text { enterprises }\end{array}$} & \multicolumn{2}{|c|}{$H M T W+F I E s$} & \multirow{3}{*}{$\begin{array}{c}E \\
A-C\end{array}$} & \multirow{3}{*}{$\begin{array}{c}F \\
B-D\end{array}$} \\
\hline & $A$ & $B$ & $C$ & $D$ & & \\
\hline & $\begin{array}{c}R \& D \\
\text { Exp. } \\
(\%)\end{array}$ & $\begin{array}{c}R \& D \\
\text { Staff } \\
(\%)\end{array}$ & $\begin{array}{l}R \& D \\
\text { Exp. } \\
(\%)\end{array}$ & $\begin{array}{c}R \& D \\
\text { Staff } \\
(\%)\end{array}$ & & \\
\hline Total/average & 0.63 & 1.44 & 0.37 & 0.92 & 0.26 & 0.52 \\
\hline Food processing & 0.14 & 0.55 & 0.05 & 0.29 & 0.10 & 0.25 \\
\hline Food manufacturing & 0.32 & 0.72 & 0.20 & 0.81 & 0.12 & -0.09 \\
\hline Beverage manufacturing & 0.48 & 0.87 & 0.59 & 0.79 & -0.11 & 0.07 \\
\hline Tobacco processing & 0.20 & 1.84 & 0.61 & 0.44 & -0.40 & 1.40 \\
\hline Textile industry & 0.27 & 0.42 & 0.32 & 0.38 & -0.05 & 0.05 \\
\hline
\end{tabular}

Notes: \# S\&T Ints: total number of S\&T institutes, R\&D Exp (\%): percent of R\&D spending out of annual sales; R\&D Staff (\%): percent of R\&D staff out of total employment. 
Table 3 Foreign R\&D in China by sector II (continued)

\begin{tabular}{|c|c|c|c|c|c|c|}
\hline \multirow[t]{3}{*}{ Sectors } & \multicolumn{2}{|c|}{$\begin{array}{l}\text { Domestic } \\
\text { enterprises }\end{array}$} & \multicolumn{2}{|c|}{$H M T W+F I E s$} & \multirow{3}{*}{$\begin{array}{c}E \\
A-C\end{array}$} & \multirow{3}{*}{$\begin{array}{c}F \\
B-D\end{array}$} \\
\hline & $A$ & $B$ & $C$ & $D$ & & \\
\hline & $\begin{array}{c}R \& D \\
\text { Exp. } \\
(\%)\end{array}$ & $\begin{array}{c}R \& D \\
\text { Staff } \\
(\%)\end{array}$ & $\begin{array}{l}R \& D \\
\text { Exp. } \\
(\%)\end{array}$ & $\begin{array}{c}R \& D \\
\text { Staff } \\
(\%)\end{array}$ & & \\
\hline $\begin{array}{l}\text { Garments and other fibre } \\
\text { products }\end{array}$ & 0.24 & 0.22 & 0.05 & 0.05 & 0.19 & 0.17 \\
\hline $\begin{array}{l}\text { Leather, furs, down and } \\
\text { related products }\end{array}$ & 0.12 & 0.29 & 0.08 & 0.09 & 0.04 & 0.19 \\
\hline $\begin{array}{l}\text { Timber processing, bamboo, } \\
\text { cane, palm fibre and straw } \\
\text { products }\end{array}$ & 0.24 & 0.22 & 0.11 & 0.14 & 0.13 & 0.09 \\
\hline Furniture manufacturing & 0.11 & 0.33 & 0.22 & 0.09 & -0.11 & 0.24 \\
\hline $\begin{array}{l}\text { Papermaking and paper } \\
\text { products }\end{array}$ & 0.26 & 0.47 & 0.33 & 0.69 & -0.07 & -0.22 \\
\hline $\begin{array}{l}\text { Printing and record medium } \\
\text { reproduction }\end{array}$ & 0.20 & 0.39 & 0.29 & 0.61 & -0.09 & -0.23 \\
\hline $\begin{array}{l}\text { Cultural, educational and } \\
\text { sports goods }\end{array}$ & 0.34 & 0.49 & 0.23 & 0.22 & 0.10 & 0.28 \\
\hline $\begin{array}{l}\text { Petroleum processing and } \\
\text { coking }\end{array}$ & 0.13 & 1.34 & 0.09 & 1.24 & 0.04 & 0.10 \\
\hline $\begin{array}{l}\text { Raw chemical materials and } \\
\text { chemical products }\end{array}$ & 0.73 & 1.66 & 0.41 & 1.49 & 0.32 & 0.17 \\
\hline $\begin{array}{l}\text { Medical and pharmaceutical } \\
\text { products }\end{array}$ & 1.20 & 2.74 & 1.19 & 2.90 & 0.01 & -0.17 \\
\hline Chemical fibre & 0.51 & 1.38 & 0.31 & 2.06 & 0.20 & -0.68 \\
\hline Rubber products & 0.78 & 1.08 & 0.34 & 0.43 & 0.44 & 0.65 \\
\hline Plastic products & 0.38 & 0.63 & 0.19 & 0.30 & 0.20 & 0.33 \\
\hline Non-metal mineral products & 0.25 & 0.52 & 0.37 & 0.57 & -0.12 & -0.05 \\
\hline $\begin{array}{l}\text { Smelting and pressing of } \\
\text { Ferrous metals }\end{array}$ & 0.58 & 1.63 & 0.20 & 1.12 & 0.38 & 0.51 \\
\hline $\begin{array}{l}\text { Smelting and pressing of } \\
\text { non-ferrous metals }\end{array}$ & 0.37 & 1.91 & 0.55 & 1.69 & -0.17 & 0.22 \\
\hline Metal products & 0.28 & 0.62 & 0.13 & 0.37 & 0.16 & 0.25 \\
\hline Ordinary machinery & 0.83 & 1.98 & 0.59 & 1.75 & 0.24 & 0.23 \\
\hline Special purpose equipment & 1.07 & 2.45 & 0.62 & 1.67 & 0.45 & 0.78 \\
\hline Transport equipment & 1.18 & 3.13 & 0.74 & 2.24 & 0.44 & 0.89 \\
\hline $\begin{array}{l}\text { Electric equipment and } \\
\text { machinery }\end{array}$ & 1.20 & 2.44 & 0.60 & 0.92 & 0.60 & 1.52 \\
\hline
\end{tabular}

Notes: \# S\&T Ints: total number of S\&T institutes, R\&D Exp (\%): percent of R\&D spending out of annual sales; R\&D Staff (\%): percent of R\&D staff out of total employment. 
Table 3 Foreign R\&D in China by sector II (continued)

\begin{tabular}{|c|c|c|c|c|c|c|}
\hline \multirow[t]{3}{*}{ Sectors } & \multicolumn{2}{|c|}{$\begin{array}{l}\text { Domestic } \\
\text { enterprises }\end{array}$} & \multicolumn{2}{|c|}{$H M T W+$ FIES } & \multirow{3}{*}{$\begin{array}{c}E \\
A-C\end{array}$} & \multirow{3}{*}{$\begin{array}{c}F \\
B-D\end{array}$} \\
\hline & $A$ & $B$ & $C$ & $D$ & & \\
\hline & $\begin{array}{l}R \& D \\
\operatorname{Exp} . \\
(\%)\end{array}$ & $\begin{array}{l}R \& D \\
\text { Staff } \\
(\%)\end{array}$ & $\begin{array}{l}R \& D \\
\text { Exp. } \\
(\%)\end{array}$ & $\begin{array}{l}R \& D \\
\text { Staff } \\
(\%)\end{array}$ & & \\
\hline $\begin{array}{l}\text { Electronic and } \\
\text { telecommunications } \\
\text { equipment }\end{array}$ & 3.49 & 6.58 & 0.64 & 1.85 & 2.85 & 4.74 \\
\hline $\begin{array}{l}\text { Instruments, metres, cultural } \\
\text { and office machinery }\end{array}$ & 1.89 & 4.11 & 0.55 & 1.28 & 1.34 & 2.83 \\
\hline Art and others & 0.48 & 0.84 & 0.07 & 0.06 & 0.41 & 0.78 \\
\hline
\end{tabular}

Notes: \# S\&T Ints: total number of S\&T institutes, R\&D Exp (\%): percent of R\&D spending out of annual sales; R\&D Staff (\%): percent of R\&D staff out of total employment.

Table 4 Results for TFP estimation

\begin{tabular}{lccc}
\hline Dependent variable: $\operatorname{LnY}$ & $B$ & Standard error & t-test \\
\hline Independent variables & & & \\
$\quad$ Constant & 1.494 & 0.258 & $5.793^{*}$ \\
$\quad$ LnL & 0.303 & 0.055 & $5.474^{*}$ \\
$\quad$ LnK & 0.759 & 0.060 & $12.605^{*}$ \\
& & & \\
\# of observations & 58 & & \\
R square & 0.925 & & \\
Adj. R square & 0.923 & & \\
Chow's test & $\mathrm{F}=0.581$ & & \\
\hline
\end{tabular}

Notes: * Variable significant at the level of 0.000 .

The number of observations is the double of the total sectors (29) where the data are available.

\subsection{Estimation of TFP}

One hypothesis for this study is to see how comparative advantages of foreign firms affect their R\&D investment decisions in China. One way to measure their competitiveness is to compare their TFP against that for their Chinese domestic counterparts. Chow's test shows that there is no significant difference between foreign invested enterprises and Chinese domestic enterprises regarding their production functions. As such, I use the pooled model to calculate TFP for foreign and Chinese domestic enterprises in different sectors (Table 4). The model is highly significant, explaining more than $90 \%$ variance in the output. Both employment and capital are significant. The results show that $1 \%$ increase of labour will lead to $0.3 \%$ increase in total 
industrial output and $1 \%$ of increase in capital will result in $0.76 \%$ increase of gross industrial output.

Table 5 shows that TFP is generally higher in high-tech industries such as transport equipment, telecommunication equipment, instruments and office equipment, petroleum, for both foreign invested enterprises and Chinese domestic enterprises. Foreign invested enterprises show higher TFP in most industries: 22 out of the 29 sectors. Interestingly, Chinese domestic enterprises did show higher productivity in a few sectors including, tobacco, leather, furs, down and related products, cultural, education and sports goods, rubber products, plastic products, and electric equipment and machinery. It is easy to understand the advantages of Chinese domestic enterprises in the tobacco industry, which is largely due to the monopoly effect. But it is surprising to note that Chinese domestic enterprises even possess advantages in some traditional labour-intensive industries, though in most cases, the difference is not big. What is more surprising is that Chinese domestic enterprises also demonstrate slight advantages than foreign firms in the electric equipment and machinery industry and their overall TFP in the sector is about $10 \%$ higher than that for their foreign counterparts. The electric equipment and machinery industry is very technology and capital intensive. How could Chinese domestic enterprises achieve higher TFP than foreign firms? Such a question would be interesting to explore in the future, though it is beyond the scope of this study.

Table 5 Comparison of FTP for foreign invested enterprises and Chinese domestic enterprises

\begin{tabular}{lccc}
\hline Sectors & $\begin{array}{c}\text { TFP for Chinese } \\
\text { domestic } \\
\text { enterprises }(A)\end{array}$ & $\begin{array}{c}\text { TFP for foreign } \\
\text { invested } \\
\text { enterprises }(B)\end{array}$ & $\begin{array}{c}\text { For } \\
\text { TFP_DomTFP } \\
\text { (B/A) }\end{array}$ \\
\hline Food processing & 5.81 & 7.24 & 1.25 \\
Food manufacturing & 3.60 & 3.86 & 1.07 \\
Beverage manufacturing & 2.97 & 3.53 & 1.19 \\
$\begin{array}{l}\text { Tobacco processing } \\
\text { Textile industry }\end{array}$ & 8.00 & 2.97 & 0.37 \\
$\begin{array}{l}\text { Garments and other fibre } \\
\text { products }\end{array}$ & 3.29 & 3.29 & 1.00 \\
$\begin{array}{l}\text { Leather, furs, down and } \\
\text { related products }\end{array}$ & 4.81 & 4.85 & 1.01 \\
$\begin{array}{l}\text { Timber processing, } \\
\text { bamboo, cane, palm fibre }\end{array}$ & 6.62 & 5.26 & 0.79 \\
and straw products & 3.60 & & 1.03 \\
$\begin{array}{l}\text { Furniture manufacturing } \\
\text { Papermaking and paper }\end{array}$ & 5.00 & 3.71 & 1.07 \\
products & 2.94 & 5.37 & 0.92 \\
$\begin{array}{l}\text { Printing and record } \\
\text { medium reproduction }\end{array}$ & 2.48 & 2.72 & 0.74 \\
$\begin{array}{l}\text { Cultural, educational and } \\
\text { sports goods }\end{array}$ & 5.47 & 3.22 & \\
\hline
\end{tabular}


Table 5 Comparison of FTP for foreign invested enterprises and Chinese domestic enterprises (continued)

\begin{tabular}{|c|c|c|c|}
\hline Sectors & $\begin{array}{c}\text { TFP for Chinese } \\
\text { domestic } \\
\text { enterprises }(A)\end{array}$ & $\begin{array}{l}\text { TFP for foreign } \\
\text { invested } \\
\text { enterprises }(B)\end{array}$ & $\begin{array}{c}\text { For } \\
\text { TFP_DomTFP } \\
\text { (B/A) }\end{array}$ \\
\hline $\begin{array}{l}\text { Petroleum processing and } \\
\text { coking }\end{array}$ & 6.96 & 7.61 & 1.09 \\
\hline $\begin{array}{l}\text { Raw chemical materials } \\
\text { and chemical products }\end{array}$ & 3.25 & 5.64 & 1.73 \\
\hline $\begin{array}{l}\text { Medical and } \\
\text { pharmaceutical products }\end{array}$ & 3.10 & 4.26 & 1.38 \\
\hline Chemical fibre & 3.74 & 3.71 & 0.99 \\
\hline Rubber products & 4.39 & 3.25 & 0.74 \\
\hline Plastic products & 4.26 & 3.39 & 0.79 \\
\hline $\begin{array}{l}\text { Non-metal mineral } \\
\text { products }\end{array}$ & 2.34 & 2.48 & 1.06 \\
\hline $\begin{array}{l}\text { Smelting and pressing of } \\
\text { ferrous metals }\end{array}$ & 4.18 & 7.32 & 1.75 \\
\hline $\begin{array}{l}\text { Smelting and pressing of } \\
\text { non-ferrous metals }\end{array}$ & 4.39 & 5.31 & 1.21 \\
\hline Metal products & 5.05 & 5.21 & 1.03 \\
\hline Ordinary machinery & 4.44 & 5.42 & 1.22 \\
\hline Special purpose equipment & 3.94 & 5.21 & 1.32 \\
\hline Transport equipment & 4.26 & 7.39 & 1.73 \\
\hline $\begin{array}{l}\text { Electric equipment and } \\
\text { machinery }\end{array}$ & 6.36 & 5.81 & 0.91 \\
\hline $\begin{array}{l}\text { Electronic and } \\
\text { telecommunications } \\
\text { equipment }\end{array}$ & 5.37 & 8.25 & 1.54 \\
\hline $\begin{array}{l}\text { Instruments, metres, } \\
\text { cultural and office } \\
\text { machinery }\end{array}$ & 3.97 & 7.69 & 1.93 \\
\hline Art and others & 4.26 & 4.31 & 1.01 \\
\hline
\end{tabular}

\subsection{Results of statistical modelling}

Two sets of analyses were conducted for different measurements of wages, one using the STWage and the other using AdjSTWage. The results are reported in Table 6. Due to the multicollinearity problem associated with the two variables SOE and Dom RD, I did not include them in the final round of analyses. This in no means suggests they are not important in understanding the presence of foreign R\&D in China. For example, the correlation coefficient between FRD_Exp and Dom_RD is 0.871, which is significant at the level of 0.01. However, the correlation between SOE and foreign R\&D presence is very weak, neither are they significant. The results indicate that the role of SOEs is not significant in explaining foreign R\&D in China. 
Table 6 Results from regression analyses II

\begin{tabular}{|c|c|c|c|c|}
\hline \multirow{2}{*}{$\begin{array}{c}\text { Dependent variable: } \\
\qquad F R D \_E x p\end{array}$} & \multicolumn{2}{|c|}{ Model 1} & \multicolumn{2}{|c|}{ Model 2} \\
\hline & $B$ & T-test & $B$ & $T$-test \\
\hline \multicolumn{5}{|l|}{ Independent variables } \\
\hline Constant & -500749 & $-4.604 * *$ & -297146 & -2.504 \\
\hline DomMkt & 28.29 & $4.310^{* *}$ & 30.22 & $3.846^{* *}$ \\
\hline FExprt & 1817.23 & $1.925^{\#}$ & 2201.56 & $1.984^{\#}$ \\
\hline STStaff & 552.55 & $2.282 *$ & 929.63 & $3.824 * *$ \\
\hline STWage & 6.49 & $2.936 * *$ & & \\
\hline AdjSTWage & & & 0.70 & 0.217 \\
\hline Patent_STStaff & -5731.19 & -1.001 & -5513.49 & -0.640 \\
\hline FMkt_Monoply & 12133.61 & $6.042 * *$ & 12993.39 & $5.480 * *$ \\
\hline ForTFP_DomTFP & -143242 & -1.562 & -263709 & $-2.644^{*}$ \\
\hline \# of observations & \multicolumn{2}{|c|}{28} & \multicolumn{2}{|c|}{28} \\
\hline R square & \multicolumn{2}{|c|}{0.854} & \multicolumn{2}{|c|}{0.795} \\
\hline Adj. R square & \multicolumn{2}{|c|}{0.806} & \multicolumn{2}{|c|}{0.726} \\
\hline
\end{tabular}

Notes: \# significant at the level of 0.10 .

* significant at the level of 0.05 .

** significant at the level of 0.01 .

The results from the two sets of regression analyses show that market is a very strong driving force in attracting foreign $R \& D$ to China: the two variables measuring China's domestic market (DomMkt) and export (FExprt) show consistent and positive impacts on the number of foreign S\&T institutes and their R\&D expenditures and they are also significant. On the supply side, the availability of S\&T talents shows consistent and significant impact on foreign $\mathrm{R} \& \mathrm{D}$, while the impact of labour costs on foreign is not conclusive. The absolute value of wage (STWage) shows positive impacts in both models, though it is only significant in one model. The positive impact of wage is contradictory to what I expect, though it is hardly surprising since many studies on foreign direct investments have revealed similar results. They argue that higher wages may also indicate the better skills of the labour, which should have positive impacts on attracting foreign investments. As such, the positive relationship between wage and foreign $\mathrm{R} \& \mathrm{D}$ investment may indicate that the attractiveness of sectors with better skilled people, which are naturally better paid. When adjusted wage (AdjSTWage) is used, the variable shows positive though insignificant impact in another model. The inconsistent relationships between wage and foreign $R \& D$ may indicate that wage is not a significant factor in explaining foreign R\&D distribution in China, though it is a critical factor for foreign companies at the national level. In another study, I also find that neither absolute wage nor adjusted wage is significant in explaining the geographic distribution of foreign $\mathrm{R} \& \mathrm{D}$ in China. I argue that the sectoral or regional difference in wage within China probably is smaller than that for the inter-country difference between China and foreign countries. As such, foreign companies may not pay close attention to the issue of labour costs once they decide to make R\&D investment in China, though labour cost is a factor 
when they decide where not to make R\&D investment in China. From the results, I may conclude that availability of educated labour is a more important factor than their costs in explaining foreign R\&D in China.

In addition, the regression analyses reveal that the impact of technology measured by the innovative productivity of labour is not significant in explaining the sectoral distribution of foreign R\&D investment. In both models, the variable Patent_STStaff shows negative impacts on foreign $\mathrm{R} \& \mathrm{D}$, though the variable is not significant in either model. Such results on the one hand confirm our hypothesis that foreign R\&D is not driven by China's technology endowment. On the other hand, the result demonstrates that the innovative capability is still weak compared to foreign companies, even after so many years of reforms.

On the impacts of comparative advantages of foreign firms on their R\&D, I find that both variables, the two models show conflicting results. To begin with, the results report positive and significant impact of market monopoly on foreign R\&D. I expect that foreign firms will make less $R \& D$ investment in sectors where they have become the dominant players: they simply do not need to conduct R\&D in order to capture the market, ultimately the profits in such sectors. However, the results show that the opposite is true: foreign firms are more likely to make R\&D investments in sectors where they are already more competitive. Furthermore, the results show negative impacts of foreign firms' productivity: foreign firms are less likely to conduct R\&D in sectors where they enjoy relative advantages measured by TFP. The direction of the relationship here follows what I expect: foreign companies are less likely to conduct R\&D in sectors where they already enjoy higher competitive advantage. The conflicting results here need more analyses, since both variables measure the relative strength of foreign companies in competition against China's domestic firms. Particularly one needs to understand why foreign companies are conducting more $R \& D$ in sectors where they already enjoy higher share in China's domestic market. One reason could be because of the reversed causal relationship between R\&D and firms' market dominance in China: foreign companies commanding higher market shares in certain sectors simply because they are more willing to invest in $R \& D$ in such sectors and $R \& D$ is precisely one factor making them more successful in such sectors than in others. If this is the case, it has clear implications for foreign investors: local $R \& D$ is significant in helping them to achieve success in foreign markets. In sectors where they meet strong competition from Chinese domestic companies, foreign companies are forced to make R\&D investments in order to be successful.

\section{Conclusions}

This study aims to answer three questions about foreign R\&D in China:

1 How extensive is foreign R\&D in China?

2 How does foreign R\&D vary in different sectors in China?

3 How important are the different drivers for explaining foreign R\&D in China, namely demand, human resources, technology, and market competition? 
The results show that foreign R\&D in China is much broader than what have been reported. Foreign companies are more likely to engage in R\&D than Chinese domestic enterprises though they are committing less resource to $R \& D$ than their Chinese domestic counterparts. This suggests that the majority of foreign R\&D investments in China are largely involved in adaptive development rather than in truly innovative research, which usually requires large amount of resources. Such results confirm findings from previous studies (von Zedtwitz, 2004; Walsh, 2003). In addition, this study reveals that foreign $\mathrm{R} \& \mathrm{D}$ are concentrated in high-tech industries, in which foreign companies are likely to conduct R\&D than those in traditional labour intensive industries. Such a pattern largely follows what is observed for China's domestic enterprises. On the third question, the study reveals that market demand and the availability of quality labour are the major drivers for foreign R\&D investments in China. However, the impact of R\&D staff's labour cost is not consistent and conflicting results have been found, which maybe due to the small sample size of this study. The results also show that the technology drive has not become significant in explaining foreign R\&D in China. Such results have confirmed the findings from previous studies (Sun et al., 2006; von Zedtwitz, 2004; Walsh, 2003).

Interestingly, this study has found conflicting results on the relationship between foreign $\mathrm{R} \& \mathrm{D}$ and their comparative advantages in technology and market. On the one hand, it finds that foreign companies are less likely to conduct $R \& D$ in sectors where they already master strong technological advantages measured by total factor productivity against China's domestic firms. Such a result is easily expected. On the other hand, this study finds positive relationships between foreign R\&D and their shares in China's domestic markets. I argue that the negative relationship between foreign R\&D and their market share may indicate the importance of R\&D in enhancing foreign companies' market performance in China, instead of being interpreted as the positive impacts of market share on R\&D of foreign firms. Such a finding for foreign companies has critical implications for foreign companies: if they want to achieve success in China's domestic market, they need to customise their technologies, and they cannot simply rely on technologies generated elsewhere. Such results may suggest that the Chinese governments and domestic firms should not expect to benefit too much from foreign R\&D activities in China. Instead they should focus on building up indigenous innovative capabilities: the majority of foreign firms will invest in $R \& D$ when they feel the competition from domestic firms.

It would be interesting to further examine how foreign $R \& D$ is interacting with China's domestic R\&D. Does foreign R\&D in China generate spillovers for China's domestic firms? This issue has serious implications for China's policy makers. So far, they have tried to attract more foreign investment in general and foreign R\&D investment in particular. The assumption is that such foreign investments will help building domestic technological capabilities. Earlier studies have examined the presence of foreign investment in general and have found significant and positive impacts on the overall performance of China's domestic enterprises (Liu and Wang, 2003). How about the impacts of foreign $R \& D$ investments in particular? Do foreign $R \& D$ investments have similar spillover impacts on innovative performance of China's domestic enterprises? This study has found that foreign R\&D and China's domestic R\&D are positively related. However, I did not examine this issue in detail. Such a question deserves further attention in the future, and it has serious implications on China's policies on foreign R\&D investments. 


\section{Acknowledgements}

The author is grateful for financial support provided by the US National Science Foundation (Project \# BCS-0552265). The research was completed when the author was on sabbatical leave in 2007 and he wishes to thank the support from California State University, Northridge.

\section{References}

Behrman, J.N. and Fisher, W.A. (1980) Overseas R\&D Activities of Transnational Companies, Oelgeschlager, Gunn \& Hain Publishers Inc., Cambridge, Massachusetts.

China State Council (2006) China Economic Census 2004, China Statistics Press, Beijing.

China State Statistical Bureau (CSSB) (2006) Statistical Yearbook of China, China Statistical Press, Beijing.

De Meyer, A. and Mizushima, A. (1989) 'Global R\&D management', R\&D Management, Vol. 19, pp.135-146.

Dunning, J.H. (1993) Multinational Enterprises and the Global Economy, Addison-Wesley, Wokingham, England.

Economic Intelligence Unit (EIU) (2004) Scattering the Seeds of Invention: The Globalization of Research and Development, Economic Intelligence Unit (EIU), Hong Kong.

Florida, R. (1997) 'The globalization of R\&D: results of a survey of foreign-affiliated R\&D laboratories in the USA', Research Policy, Vol. 26, pp.85-103.

Florida, R. and Kenney, M. (1994) 'The Globalization of Japanese R\&D: the economic geography of Japanese R\&D investment in the United States', Economic Geography, Vol. 70, pp.344-370.

Freeman, R.B. (2005) 'Does globalization of the scientific/engineering workforce threaten US economic leadership?', NBER Working Paper 11457.

Gassmann, O. and Han, Z. (2004) 'Motivations and barriers of foreign R\&D activities in China', $R \& D$ Management, Vol. 34, pp.423-437.

Great Wall Enterprise Institute (GEI) (2001) 'Multinational R\&D investment in Beijing', internal report.

Hakanson, L. and Nobel, R. (1993) 'Determinants of foreign R\&D in Swedish multinationals', Research Policy, Vol. 22, pp.397-411.

He, C. (2003) 'Entry mode and location of foreign manufacturing enterprises in China', Eurasian Geography and Economics, Vol. 44, pp.399-417.

Howells, J.R. (1990) 'The location and organisation of research and development: new horizons', Research Policy, Vol. 19, pp.133-146.

Howells, J.R. (1995) 'Going global: the use of ICT network in research and development', Research Policy, Vol. 24, pp.169-184.

Kuemmerle, W. (1997) 'Building effective R\&D capabilities aboard', Harvard Business Review, March-April, pp.61-70.

Kuemmerle, W. (1999) 'Foreign direct investment in industrial research in the pharmaceutical and electronics industries-results from a survey of multinational firms', Research Policy, Vol. 28 , pp.179-193.

Liu, X. and Wang, C. (2003) 'Does foreign direct investment facilitate technological progress? Evidence from Chinese industries', Research Policy, Vol. 32, pp.945-953. 
Mansfield, E., Teece, D. and Romeo, A. (1979) 'Overseas research and development by US-based firms', Economica, Vol. 46, pp.187-196.

National Science Foundation (NSF) (2006) 'Science and engineering indicators 2006', available at http://www.nsf.gov/statistics/seind06/.

Reddy, P. (1997) 'New trends in globalization of corporate R\&D and implications for innovation capability in host countries: a survey from India', World Development, Vol. 25, pp.1821-1837.

Reddy, P. and Sigurdson, J. (1997) 'Strategic location of R\&D and emerging patterns of globalization: the case of Astra Research Center India', International Journal of Technology Management, Vol. 14, pp.344-361.

Ronstadt, R. (1977) Research and Development aboard by U.S. Multinationals, Praeger, New York.

Schwaag Serger, S. (2006) 'China: from shop floor to knowledge factory?', in M. Karlsson (Ed.): The Internationalization of Corporate $R \& D$ : Leveraging the Changing Geography of Innovation, IPTS, Sweden.

Sun, Y. (2002) 'Sources of innovation in China's manufacturing sector: imported or developed in-house?', Environment and Planning A, Vol. 34, pp.1059-1072.

Sun, Y. (2003) 'Strategic or tactical? Foreign research and development in developing countries, a case study of China', Asian Geographer, Vol. 22, pp.143-167.

Sun, Y. and Wen, K. (2007a) 'Country relational distance, organizational power and R\&D managers: understanding environmental challenges for foreign R\&D in China', Asia Pacific Business Review, Vol. 13, pp.425-450.

Sun, Y. and Wen, K. (2007b) 'Uncertainties, imitating behaviors and foreign R\&D locations: Explaining the over-concentration of foreign R\&D in Beijing and Shanghai within China', Asia Pacific Business Review, Vol. 13, pp.405-424.

Sun, Y., Du, D. and Huang, L. (2006) 'Foreign R\&D in developing countries: empirical evidence from Shanghai, China', The China Review, Vol. 6, pp.67-91.

Sun, Y., Von Zedtwitz, M. and Simon, D.F. (Eds.) (2008) Global $R \& D$ in China, Routledge, London.

Terry, E. (1996) ‘An Asian Paradigm’, Atlantic Economic Journal, Vol. 24, pp.183-199.

UNCTAD (2005) World Investment Report 2005: Transnational Corporations and the Internationalization of $R \& D$, available at http://www.unctad.org/Templates/WebFlyer.asp?intItemID=3489\&lang=1.

von Zedtwitz, M. (2004) 'Managing foreign R\&D laboratories in China', $R \& D$ Management, Vol. 34, pp.439-452.

Walsh, K. (2003) Foreign High-Tech R\&D in China, The Henry L. Stimson Center 2003, available at http://www.stimon.org.

Walsh, K.A. (2007) 'China R\&D: a high-tech field of dreams', Asia Pacific Business Review, Vol. 13, pp.321-336.

Xue, L., Shen, Q. and Wang, S. (2001) 'Establishment of transnational-funded R\&D institutes in China and its significance', Foreign Investment in China (in Chinese, Zhongguo Waizi), Vol. 98, pp.38-39. 


\section{Notes}

1 In Chinese government statistics, S\&T staff refers to people engaged in science and technology activities, including people directly participating in research and development as well as those who provide administrative support and other services to R\&D personnel. The core part of S\&T staff consists of scientists and engineers engaging in R\&D activities. I understand it might be better to use some other measurements such as people with advanced degrees in each sector. Unfortunately, such data are not available.

2 Here, I assume that S\&T staff is the primary sources of innovations in Chinese industries and innovations can be majored by patent grants. I understand that there exists significant weakness among these two assumptions. First, innovation may come from other people as well in an industry, not just the S\&T staff. Second, innovation is not just about technological innovation, and it includes new practices in many aspects that are beyond technological development such as new management practices and new business models. Third, technological innovation is not equivalent to patents. As many authors have pointed the number of weaknesses associated with using patents as the indicators of industrial technological innovation. However, I believe such a measure provides a reasonable indicator for the innovativeness and productivity of S\&T staff.

3 Using number of R\&D centres would be ideal, which, unfortunately, is not reported by the census.

4 From now on, in this study, HKMT will be used to denote those enterprises with investment from Hong Kong, Marco, Taiwan, and FIEs will be used to refer to those foreign invested enterprises from areas other than HKMT. When not specified, foreign invested firms, or foreign firms, foreign enterprises will refer to the combined of these two types of foreign investments.

5 I have tried unsuccessfully in different ways to confirm the number of foreign R\&D centres. Indeed, there is no number reported after 2005, for reasons I do not know. I suspect it is because foreign $\mathrm{R} \& \mathrm{D}$ in China has become a concern for many foreign countries, since such issues have serious implications for national economic competitiveness. 